\title{
Natural Rubber Latex Used as Drug Delivery System in Guided Bone Regeneration (GBR)
}

\author{
Rondinelli Donizetti Herculano ${ }^{\mathrm{a}}$, Cecília Pereira Silva ${ }^{\mathrm{a}}$, Cibele Ereno ${ }^{\mathrm{b}}$ \\ Sérgio Augusto Catanzaro Guimaraes ${ }^{\mathrm{b}}$, Angela Kinoshita ${ }^{\mathrm{a}, \mathrm{b}}$, Carlos Frederico de Oliveira Graeff \\ a Departamento de Física e Matemática, FFCLRP - USP, \\ Av. Bandeirantes, 3900, 14040-901 Ribeirão Preto - SP, Brazil \\ ${ }^{\mathrm{b}}$ Universidade do Sagrado Coração, \\ Rua Irmã Arminda, 10-50, 17011-160 Bauru - SP, Brazil \\ ${ }^{\mathrm{D}}$ Departamento de Física, FC - UNESP, \\ Av. Luis Edmundo Carrijo Coube, 14-01, 17033-360 Bauru - SP, Brazil
}

Received: December 20, 2008; Revised: February 9, 2009

\begin{abstract}
In this work, we propose natural rubber latex (NRL) membranes as a protein delivery system. For this purpose Bovine Serum Albumin (BSA) was incorporated into the latex solution for in vitro protein delivery experiments. Different polymerization temperatures were used, from -10 to $27^{\circ} \mathrm{C}$, in order to control the membrane morphology. These membranes were characterized by Scanning Electron Microscopy (SEM), Atomic Force Microscopy (AFM), as well as the Lowry Method to measure the BSA release. SEM and AFM microscopy analysis showed that the number, size and distribution of pores in NRL membranes can be varied, as well as its overall morphology. We have found that the morphology of the membrane is the predominant factor for higher protein release, compared with pore size and number of pores. Results demonstrated that the best drug-delivery system was the membrane polymerized at RT $\left(27^{\circ} \mathrm{C}\right)$, which does release $66 \%$ of its BSA content for up to 18 days. Our results indicate that NRLb could be used in the future as an active membrane that could accelerate bone healing in GBR.
\end{abstract}

Keywords: artificial membrane, bone regeneration, biomaterials, guided bone regeneration, latex

\section{Introduction}

Natural rubber latex (NRL) extracted from Hevea brasiliensis has been widely used in the manufacturing of gloves, condoms, balloons, and parts of medical and dental equipment ${ }^{1-4}$. Typically for those applications, the processing of NRL was basically the same as those found in the tyres industry. However recently, several new biomedical applications for NRL have been proposed using a different manufacturing process (NRLb) $)^{5-9}$. Of special interest, NRLb has shown to stimulate angiogenesis, cellular adhesion and the formation of extracellular matrix ${ }^{10}$, promoting the replacement and regeneration of tissue ${ }^{11}$.

It is well known in the literature that NRL can give allergic reactions and has cytoxicity problems, which is of great concern especially on these new applications where NRL is used inside the human body. However NRLb is processed avoiding the use of chemicals such as carbamates and sulphur, as well as does not suffer any heat treatments. Apparently this way of producing NRLb produces a much better biocompatible material. In fact, NRLb is now commercialized in Brazil and other 60 countries as a band-aid curative $\left(\mathrm{BIOCURE}^{\circledR}\right.$ ) for the treatment of ulcers in diabetic patients among other applications ${ }^{12}$.

In a previous study, we have tested NRLb as an occlusive membrane for Guided Bone Regeneration (GBR) with promising results ${ }^{13}$ We tested our membrane in a critical defect in the rabbit calvaria, and did show that the wound was healed only with NRLb. NRLb worked as a passive barrier membrane that prevented epithelial and connective tissue migration, thus facilitating the proliferation and migration of regenerative potential cells, such as bone cells, into the protected wound. One possible way to accelerate bone regeneration would be to incorporate bone morphogenetic protein (BMPs) in NRLb. BMPs have strong bone-inductive activity and many works have been dedicated to the development of delivery systems that sustain their gradual release for dental and orthopedic use ${ }^{14-17}$. One key issue in this particular problem is that bone regeneration is a long term processes, typically in humans of the order of 8-16 weeks ${ }^{18-21}$. Thus the ideal membrane would have to release BMPs along many weeks. So in this work we have used different polymerization conditions in order to control the protein release of NRLb. Instead of using BMPs, in our study we used BSA that has similar molecular weight however is cheaper. NRLb polymerized under different conditions, and with the incorporation of BSA was characterized by Scanning Electron Microscopy (SEM) and Atomic Force Microscopy (AFM), while BSA release from the membrane was characterized by the Lowry Method ${ }^{22,23}$. Results demonstrated that the NRLb membrane can release BSA for up to 18 days.

\section{Experimental Section}

The latex solution used in this work consisted of a mixture of a noncontrolled variety of clones extracted from Hevea brasiliensis. The latex solution was provided by ESALQ-USP, Piracicaba, Brazil. After extraction, ammonia was used to keep the latex liquid, and this material was centrifuged at $8000 \mathrm{~g}$. The centrifugation was employed to 
reduce the natural protein content of $\mathrm{NRLb}^{10}$. Bovine Serum Albumin (BSA) was purchased from INLAB Ltd., Brazil.

Two types of membranes were used: A) NRLb (2 mL of natural rubber) and; B) NRLbBSA ( $2 \mathrm{~mL}$ of natural rubber $+1 \mathrm{~mL}$ of BSA solution (10 mg. $\left.\mathrm{mL}^{-1}\right)$ ). These membranes were prepared by pouring the latex or latex+BSA solution in a stainless steel plate with $5.00 \pm 0.05 \mathrm{~cm}$ diameter, and left at different temperatures for polymerization: $27^{\circ} \mathrm{C}$ (Room temperature), $-1{ }^{\circ} \mathrm{C}$, and $-10^{\circ} \mathrm{C}$. Typically the membranes were left for 02 days to fully polymerize before use. The temperatures chosen are known to change the porosity of the membranes ${ }^{24,25}$.

For the protein release study NRLb and NRLbBSA membranes were placed in $200 \mathrm{~mL}$ of aqueous solution, where the release behavior was observed. Aliquots of this solution were collected during an interval ranging from 10 to 24,000 minutes. We determined the protein release as a function of time using the Lowry Method. ${ }^{26,27}$. To determine the concentration of BSA released into the solution it was necessary to take into account that NRLb does also release proteins that absorb at the same wavelength as the BSA. Thus the NRLb release curve was subtracted from the NRLbBSA release curve.

The pore distribution in NRLb membrane was observed using a Scanning Electron Microscocopy (SEM) model Zeiss ${ }^{\circledR}$ EVO 50 $(15 \mathrm{KV})$. The surface topography of the NRL membrane was examined in a Shimadzu ${ }^{\circledR}$ SPM-9600 operating in the tapping mode (scan size 25 and $50 \mu \mathrm{m}$ ). The average roughness (Ra) of the substrate surface was directly calculated from the AFM image.

\section{Results and Discussion}

Figure 1 shows typical SEM images of membranes polymerized at different temperatures. As can be seen the pore sizes and density vary with polymerization temperature. NRLb polymerized at RT (Figure 1a), has apparently no pores, while those membranes polymerized at $-1{ }^{\circ} \mathrm{C}$ and $-10{ }^{\circ} \mathrm{C}$ do have. The density of pores is higher as the polymerization temperature diminishes. Pore sizes with diameters ranging from 0.50 to $1.63 \mu \mathrm{m}$, were observed on the NRLb membrane polymerized at $-1{ }^{\circ} \mathrm{C}$ (Figure $1 \mathrm{~b}$ ), while the film polymerized at $-10{ }^{\circ} \mathrm{C}$ displayed pore sizes of similar dimensions $(\sim 0.86 \pm 0.12) \mu \mathrm{m}$ (Figure 1c).

Figures $2 \mathrm{a}$ and $2 \mathrm{~b}$ shows AFM images of membranes polymerized at RT and $-1{ }^{\circ} \mathrm{C}$, respectively. The image of the membrane polymer- ized at $-10{ }^{\circ} \mathrm{C}$ is similar to Figure $2 b$, and thus not shown. As can be seen in Figure 2a, the polymer structure in this case is characterized by linear chains, or linear bundles of chains, whereas in Figure $2 b$ these linear chains are not seen. The appearance of linear chains is followed by a higher surface roughness, see insets of Figure 2.

In Figure 3 BSA release as a function of time is presented for membranes polymerized in similar conditions to the ones presented in Figure 1. In the inset of this figure, the release rate is also presented until the saturation point. The concentration of released BSA increases asymptotically for all samples. The release from the membrane polymerized at RT is higher than those polymerized at $-1{ }^{\circ} \mathrm{C}$ and at $-10{ }^{\circ} \mathrm{C}$. The 3 membranes reach saturation at different concentrations. In the other words, the total concentration of released BSA depends on the latex polymerization temperature.

As already mentioned in the introduction, the main concern of this study was to optimize the BSA release in small rates. According to $\mathrm{Woo}^{17}$, sustained release implants induce better bone healing compared with those that do not.

Based on SEM results (Figure 1), we observed that the pore size and number can affect the BSA release. No pores were observed on the NRLb membrane polymerized at RT, and it had the highest BSA release. Therefore our results indicate that the way the chains are organized during polymerization is the dominant factor concerning protein release. The formation of pores may correlate with a higher cross-linking, forming in fact a denser matrix for BSA release (NRLb membranes polymerized at $-1{ }^{\circ} \mathrm{C}$ and $-10{ }^{\circ} \mathrm{C}$ ).

The experimental data in Figure 3 were fitted by Double rectangular hyperbola function. After integration of these curves until 285 hours, the total amount of BSA released by the three membranes in $200 \mathrm{~mL}$ aqueous solution were: $13.24 \mathrm{mg}$ ( $44.1 \%$ of the BSA used in the beginning) for RT membrane and $3,73 \mathrm{mg}(12.4 \%)$ for $-1{ }^{\circ} \mathrm{C}$ and $7,52 \mathrm{mg}(25.1 \%)$ for $-10^{\circ} \mathrm{C}$ membranes respectively. After 18 days the NRLb membrane polymerized at RT released $20.54 \mathrm{mg}$ of BSA, or $68.4 \%$ of the amount used during polymerization.

As mentioned earlier the controlled release of proteins are of interest for medical applications, since the dose can be adjusted according to the necessity of the patient. Our results indicate that with very simple changes in NRLb preparation we could control BSA release up to 18 days, thus making them promising materials for protein release for in vivo applications ${ }^{28-31}$.

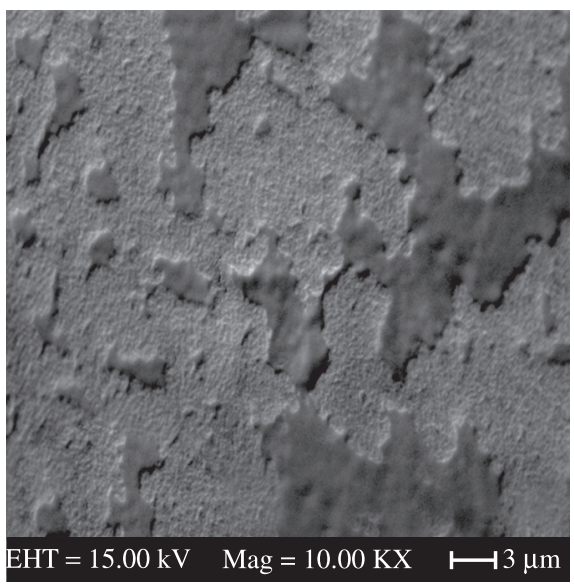

(a)

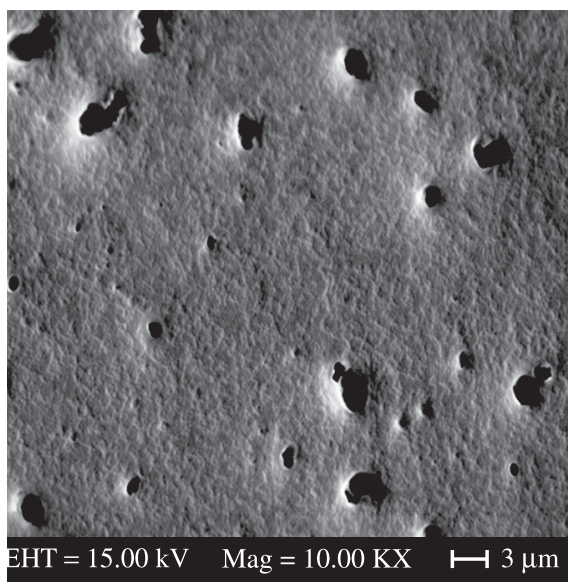

(b)

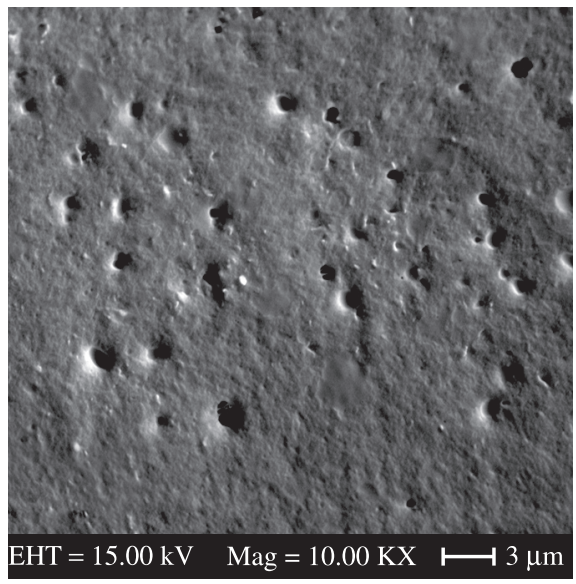

(c)

Figure 1. SEM images (magnification: $x$ 10,000) of NRLb membranes a) Polymerized at RT, b) Polymerized at $-1{ }^{\circ} \mathrm{C}$ and c) Polymerized at $-10{ }^{\circ} \mathrm{C}$. Notice the difference in the size pores. 

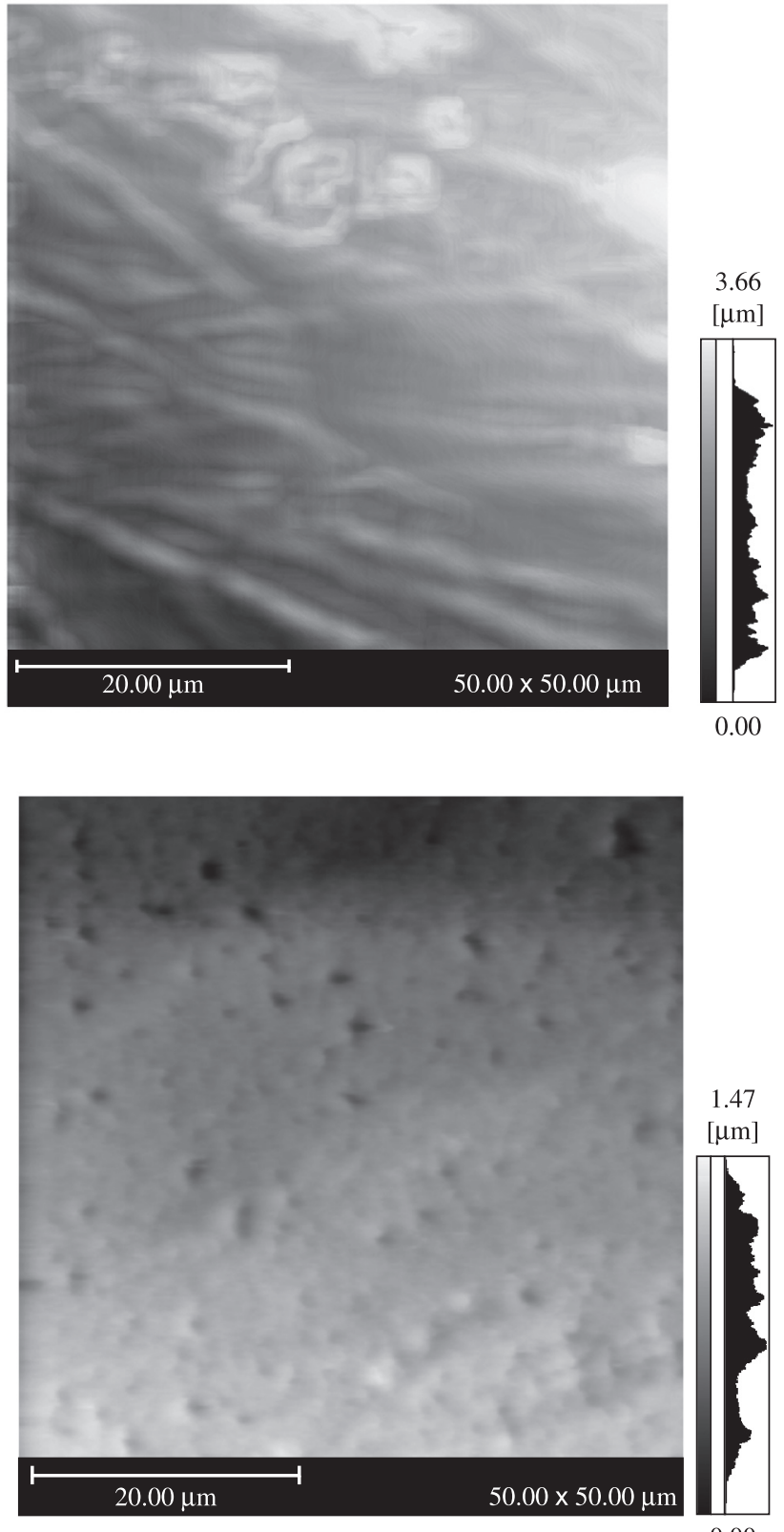

Figure 2. AFM images of NRLb membranes: a) Polymerized at RT; and b) Polymerized at $-1{ }^{\circ} \mathrm{C}$.

\section{Conclusion}

We have prepared natural rubber latex membranes containing BSA as a model system for Guided Bone Regeneration (GBR). Membranes prepared at different polymerization temperatures were analyzed. SEM and AFM microscopy analysis showed that the polymerization temperature has a strong influence on pore distribution. By decreasing the temperature the pore density increases. In fact for membranes prepared at RT, no pores could be seen with a magnification of 10,000 . However the RT membrane was characterized by structures that indicate the formation of linear bundles of chains. In what concerns BSA release the presence of this linear bundles was responsible for a higher release rate. Results demonstrated that the NRLb membrane polymerized at RT can release BSA for 18 days.

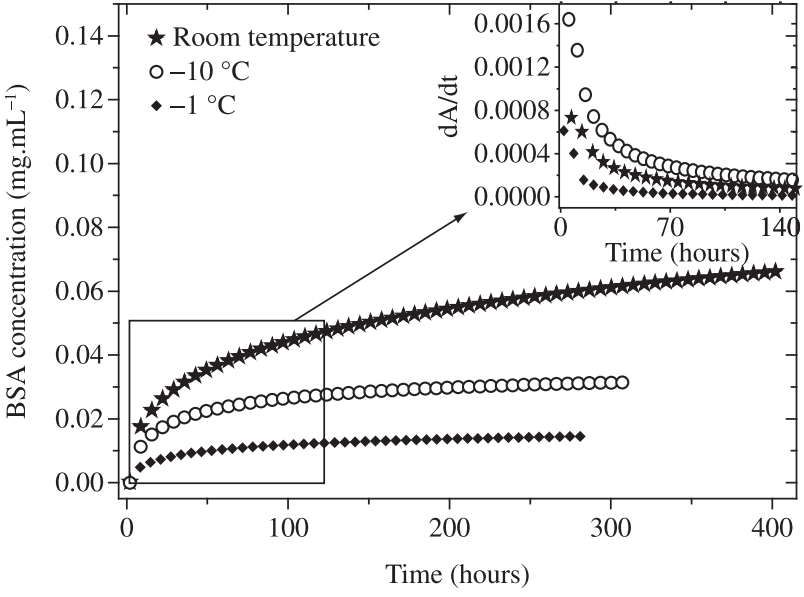

Figure 3. BSA release as a function of time for NRLb membranes prepared at different temperatures: $\mathrm{RT},-10^{\circ} \mathrm{C}$ and $-1{ }^{\circ} \mathrm{C}$.

Our results indicate that NRLb could be used in the future as an active membrane that could accelerate bone healing in GBR.

\section{Acknowledgements}

We are grateful to J. L. Aziani, C. A. Brunello for technical support and Dr. Iouri Borissevitch for the use of the Beckman DU-640 Spectrophotometer. This work received financial support from FAPESP, CNPq/IMMP and CAPES.

\section{References}

1. Hasma H, Othman AB. Barrier Performance of NR, Vinyl and Nitrile Gloves on Puncture. In Conference RAPRA, 2001 December 4-5; Munich, Germany. Paper presented at the "Latex 2001".

2. Neves-Junior WFP, Ferreira M, Alves MCO, Graeff CFO, Bernardes MS, Coutinho-Netto J, Mulato M. Influence of fabrication process on the final properties of natural-rubber latex tubes for vascular prosthesis. Brazilian Journal of Physics. 2006; 36(2B): 586-591.

3. Hasma H, Othman AB, Fauzi MS. Barrier integrity of punctured gloves: NR superior to vinyl and nitrile. Journal of Rubber Research. 2003; 6(4): 231-240.

4. Neves-Junior WFP, Graeff CFO, Ferreira M, Mulato M, Bernardes MS and Coutinho-Netto J. Elastic properties of natural rubber tubes produced by dip-coating. Journal of Applied Polymer Science. 2006; 100(1): 702-707.

5. Herculano RD, Brunello CA, Graeff CFO. Solid state Nitric Oxide sensor using a latex rubber matrix. Macromolecular Symposia. 2006; 245-246(1): 529-532.

6. Balabanian CA, Coutinho Netto J, Lamano-Carvalho TL, Lacerda SA, Brentegani LG. Biocompatibility of natural latex implanted into dental alveolus of rats. Journal of Oral Science. 2006; 48(4):201-205.

7. Paulo NM, Silva MAM, Conceição M. Biomembrane of natural latex (Hevea brasiliensis) with polylysine $0,1 \%$ for the perineal Hernirrhaphy in a dog. Acta Scientiae Veterinariae. 2005; 33(1): 79-82.

8. Herculano RD, Brunello CA, Graeff CFO. Optimization of a novel Nitric Oxide Sensor using a latex rubber matrix. Journal of Applied Science. 2007; 7(23): 3801-3805.

9. Pinho ECCM, Sousa SJF, Schaud F, Lachat JJ. Uso experimental da biomembrana de látex na reconstrução conjuntival. Arquivos Brasileiros de Oftalmologia. 2004; 67(1): 27-32. 
10. Mrué F, Coutinho-Netto J, Ceneviva R, Lachat JJ, Thomazini JA, Tambelini $\mathrm{H}$. Evaluation of the biocompatibility of a new biomembrane. Materials Research. 2004; 7(2):277-283.

11. Frade MAC, Valverde RV, Assis RVC, Coutinho-Netto J, Foss NT. Chronic phlebopathic cutaneous ulcer:a therapeutic proposal. International Journal of Dermatology. 2001; 40(3): 237-240.

12. Pele Nova-Biocure. [home page on the internet]. Available from: http:// www.pelenova.com.br/site/. Acess: 2008 July.

13. Ereno C, Catanzaro-Guimarães SA, Herculano RD, Silva CP, Graeff CFO, Tavano O, Baffa O, Kinoshita A. Study of latex film as an occlusive membrane for guided bone regeneration. Journal of Materials Science: Materials in Medicine (paper unpublished).

14. Müller F, Rohrer H, Vogel-Höpker A. Bone morphogenetic proteins specify the retinal pigment epithelium in the chick embryo. Development. 2007; 134(19): 3483-3493.

15. Jung RE, Glauser R, Schärer P, Hämmerle CHF, Sailer HF, Weber FE. Effect of rhBMP-2 on guided bone regeneration in humans: A randomized, controlled clinical and histomorphometric study. Clinical Oral Implants Research. 2003; 14(5): 556-568.

16. Oshin AO, Stewart MC. The role of bone morphogenetic proteins in articular cartilage development, homeostasis and repair. Veterinary and Comparative Orthopaedics and Traumatology. 2007; 20(3): 151-158.

17. Woo BH, Fink BF, Page R, Schrier JA, Woo Jo Y, Jiang G, DeLuca M, Vasconez HC, DeLuca PP. Enhancement of bone growth by sustained delivery of recombinant human bone morphogenetic protein-2 in a polymeric matrix. Pharmaceutical Research. 2001; 18(12): 1747-1753.

18. Kim S, Kim SS, Lee SH, Ahn SE, Gwakd SJ, Songe JH, Kim BS, Chung HM. In vivo bone formation from human embryonic stem cell-derived osteogenic cells in poly (D,L-lactic-co-glycolic acid)/hydroxyapatite composite scaffolds. Biomaterials. 2008; 29(8): 1043-1053.

19. Alvarez H, Castro C, Moujir L, Perera A, Delgado A, Soriano I, Sanchez E. Efficacy of ciprofloxacin implants in treating experimental osteomyelitis. Journal of Biomedical Materials Research Part B. 2008; 85B(1): 93-104.

20. Kirker-Head CA. Potential applications and delivery strategies for bone morphogenetic proteins. Advanced Drug Delivery Reviews. 2000; 43(1): $65-92$
21. Johnson EE, Urist MR, Finerman GA. Repair of segmen tal defects of the tibia with cancellous bone grafts augmented with human bone morphogenetic protein: A preliminary report. Clinical Orthopaedics and Related Research. 1988; 236:249-257.

22. Folin O, Denis W. On phosphotungstic-phosphomolybdic compounds as color reagents. Journal of Biological Chemistry. 1912; 12(2):239-243.

23. Folin O, Ciocalteu V. On tyrosine and tryptophane determinations in proteins. Journal of Biological Chemistry. 1927; 73(2): 627-650.

24. Lloyd DR, Kinzer KE, Tseng HS. Microporous membrane formation via thermally induced phase separation. I. Solid-liquid phase separation. Journal of Membrane Science. 1990; 52(3):239-261.

25. Lloyd DR, Kim SS, Kinzer KE. Microporous membrane formation via thermally-induced phase separation. II. Liquid-liquid phase separation. Journal of Membrane Science. 1991; 64(1-2): 1-11.

26. Tattini Jr. V, Parra DF, Pitombo RNM. Influência da taxa de congelamento no comportamento físico-químico e estrutural durante a liofilização da albumina bovina. Revista Brasileira de Ciências Farmacêuticas. 2006; 42(1): 127-136.

27. Ereno C, Graeff CFO, Herculano RD, Pereira CP, Guimarães-Catanzaro AS, Kinoshita A. Study of substances delivery from latex film using spectrophotometry Lowry method and UV applied to bone guided regeneration. In: Proceedings of the Five Annual Meeting of the Brazilian Materials Research Society - SBPMat; 2006 October 8-12; Florianópolis. Brazil: Costão do Santinho Resort \& SPA; 2006. p. 7-8.

28. Oliveira JAA, Hyppolito MA, Coutinho-Netto J, Mrué F. Miringoplastia com a utilização de um novo material biossintético. Revista Brasileira de Otorrinolaringologia. 2003; 69(5): 649-655.

29. Thomazini JA, Mrué F, Coutinho-Netto J, Lachat JJ, Ceneviva R, Zborowski AC. Morphological and biochemical characterization of a prosthesis manufactured from natural latex of Hevea brasiliensis for medical utilization. Acta Microscopica. 1997; 6(Suppl. B): 798-799.

30. Frade MAC, Brum-Cursi I, Fortes-Andrade F, Coutinho-Netto J, Barbetta FM, Foss NT. Management of diabetic skin wounds with a natural latex biomembrane. Medicina Cutánea Ibero-Latina-Americana. 2004; 32(4): 157-162.

31. Ciapetti G, Stea S, Pizzoferrato A, Checchi L, Pelliccioni GA. A latex membrane, as an alternative device in the GTR technique: preliminary report on its biocompatibility. Journal of Materials Science: Materials in Medicine. 1994: 5(9-10): 647-650. 